\title{
A COMPARATIVE STUDY OF THE BEGINNING OF THE 11TH ACT OF THE TOCHARIAN A MAITREYASAMITINĀTAKA AND THE OLD UYGHUR MAITRISIMIT ${ }^{*}$
}

\author{
MiCHAËL PEYROT-ABLET SEMET \\ Leiden University Centre for Linguistics, Leiden University \\ Postbus 9515, 2300 RA Leiden, The Netherlands \\ m.peyrot@hum.leidenuniv.nl \\ Dresdener Straße 34B, D-10179 Berlin, Germany \\ e-mail: ablet.semet@t-online.de
}

\begin{abstract}
The Tocharian A Maitreyasamitinătaka, a long dramatic text about the future Buddha Maitreya that is translated into Old Uyghur prose as the Maitrisimit, is one of the most important texts of Tocharian and Old Uyghur Buddhism. It is of crucial importance for Tocharian studies because even smaller fragments can often be interpreted successfully with the help of the better preserved Old Uyghur parallels. In this paper, the beginning of the 11th act about the birth of Maitreya is studied, comparing the Tocharian A and Old Uyghur fragments which are in part parallel and in part complementary.
\end{abstract}

Key words: Tocharian A, Old Uyghur, Maitreyasamitināțaka, Maitrisimit, Central Asian Buddhism, Xīnjiāng.

\section{Introduction}

The Tocharian A Maitreyasamitinattaka and the Old Uyghur Maitrisimit are the prime example of Tocharian-Uyghur cultural and linguistic contacts, and arguably belong to the most important texts of Tocharian and Old Uyghur Buddhism. The Tocharian A Maitreyasamitinātaka is a Buddhist play that relates the life and birth of the future Buddha Maitreya. The text was long: it comprised an introduction and twenty-seven acts of approximately ten to fifteen leaves each. Although the text was written down in beautiful manuscripts that were certainly enjoyed in their own right, it is probable that it was also performed on stage in a certain form. draft.

* We are grateful to Georges-Jean Pinault (Paris) for the valuable comments on an earlier 
The Old Uyghur Maitrisimit is based on the Tocharian A Maitreyasamitinatta$k a$, but is not an exact translation: it is faithful to the original, but is adapted to meet the requirements of Old Uyghur stylistics and practically never fully literal. Most importantly, the Tocharian A text is in so-called campū style with a mixture of prose and verse, the latter being normally reserved for longer portions of direct speech. It further contains (very restricted) stage directions about the place where a certain scene is situated, and at the end of an act a typical lcär poñs' 'all have left [the scene]' is found (cf. Pinault 2008, pp. 405-409; 2015). In the Old Uyghur version, the verse passages have been transformed into prose, and the so-called stage directions have disappeared. Thus, the character of the Old Uyghur text is decidedly different and there are no indications that it was meant to be performed on stage.

The exact dating of the text and the extant manuscripts is disputed, but the Old Uyghur Maitrisimit may be from the 10th century CE and the Tocharian A Maitreyasamitinātaka must be a little older, perhaps from the 8th century, though some manuscripts may be younger. Fragments of the Tocharian A text can be assigned to six different manuscripts. Five of these come from the site Šrčuq close to present-day Qarašähär (Yānqí) in Xīnjiāng, North-West China (the official find site of the socalled Yānqí manuscript, Qígèxīng, is in fact identical with Šorčuq), and one is from Qočo (Gāochāng) in Turfan region (Burlak - Itkin 2004). The Old Uyghur text is attested in fragments of three different manuscripts: the oldest two are from Murtuq and Sängim (alternatively also spelled Sänim; the modern Uyghur form is Singim) in the Turfan oasis, respectively, and the third, which is the best preserved, is from Qomul (Hāmì, found in the villages Tömürti and Närnasi; Israpil-Laut-Semet 2013). The Old Uyghur manuscripts present different text versions: the Sängim and Murtuq versions are older, while the Qomul version is slightly different (Laut 1986).

Although the Tocharian A text is older and certainly the source of the Old Uyghur text, comparative studies usually proceed from the Old Uyghur version, which is much better preserved. But even though both texts have always had the central place in research that they deserve (cf. in particular Müller-Sieg 1916), complete editions, let alone a full comparative analysis, are still lacking. Important progress has been made by Geng - Laut-Pinault (2004) who also provide a bibliography.

In this paper, we present a comparative analysis of the beginning of the 11 th act of the Old Uyghur Maitrisimit and the Tocharian A Maitreyasamitinattaka. So far 5 Tocharian A fragments could be assigned to the 11th act (Pinault 1999, pp. 199200), two of which, A299 and A274, belong to the beginning of it. The 11th act is well preserved in the Old Uyghur Qomul (Hāmì) version and has been edited and translated by Geng-Klimkeit-Laut (1988). However, the first two leaves of the act are missing in the Qomul manuscript. Meanwhile, additional fragments of the beginning of this act belonging to the Sängim manuscript have been found and identified (Yoshida 1991; Israpil 2009; 2013; 2015, pp. 127-148). These have been presented by Semet-Äysa in a recent article (2015) together with a translation of the Tocharian A parallel and references to the Buddhist paintings of the Dunhuang grottoes.

In subsequent collaborative work of the present authors the comparison of the Tocharian A and Old Uyghur texts could be refined, which has led to a thoroughly 
revised translation of the Tocharian A text. Taking into account several better text readings of Israpil (2013), the comparative analysis has also made a better understanding of the Old Uyghur fragments possible. In particular, the position of the fragment from the second leaf of the 11th act of the Sängim manuscript could be established more exactly. Furthermore, a number of improvements in text and translation have been made.

The 11th act contains the prophecy of Maitreya's birth, then his birth itself, and finally his childhood. The passage under discussion is from the beginning of the 11th act in which Maitreya's birth is prophesied by means of five dreams of his mother, Brahmāvatī. These five dreams, which exemplify five types of birth, are explained by brahmins. ${ }^{1}$

\section{Correspondences between the Tocharian A and Old Uyghur Fragments}

The two relevant Tocharian A fragments are A299 and A274. Fragment A299 preserves the end of the 10th and the beginning of the 11th act. Fragment A274 is to be placed a little further and there is a lacuna between the two fragments. Unfortunately, the fragments belong to different manuscripts: A299 belongs to M- $\beta$ (A251-A294, see CETOM) and A274 belongs to M- $\gamma$ (A295-A305). Therefore, the exact size of the lacuna is unknown. If in the Old Uyghur Sängim manuscript the 11th act began on a new leaf, as usual, the lacuna between A299 and A274 may have been approximately 10 lines, i.e. the lacuna was a little larger than 8 Tocharian A lines (one side of a leaf), but definitely smaller than 16 lines (both sides of a leaf).

The beginning of the 11th act of the Old Uyghur Maitrisimit is not preserved. Of the Qomul version the first two leaves are missing, but of the Sängim version a fragment of the second leaf has been preserved. There is thus no Old Uyghur parallel for A299, but the verso of the fragment of the second leaf of the Old Uyghur Sängim version corresponds to the beginning of A274. Since A274 also has a parallel in the third leaf of the Sängim version, it is essential to estimate the size of the lacuna between the fragment of the second leaf and the third leaf of the Sängim version, which must have been very small; perhaps the last line of the fragment was even the last line of the whole leaf, i.e. line 31.

The correspondences between the Tocharian A fragments and the two Old Uyghur versions are given in the table below.

\begin{tabular}{|c|c|c|c|}
\hline Tocharian A & Sängim & Qomul (Hāmì) & Old Uyghur continuous \\
\hline A299a8 & lost & & \\
\hline A299b8 & lost & & \\
\hline lost & $11.2 \mathrm{r} 15$ & & 001 \\
\hline lost & $11.2 \mathrm{r} 31$ & & 017 \\
\hline
\end{tabular}
222-227).

\footnotetext{
${ }^{1}$ For more details on the contents and context of this passage, see Semet-Äysa (2015, pp.
} 


\begin{tabular}{llll} 
Tocharian A & Sängim & Qomul (Hāmi) & Old Uyghur continuous \\
\hline A274a1 & lost & \\
A274a2 & $11.2 \mathrm{v} 15-17$ & & $018-020$ \\
A274a3 & $11.2 \mathrm{v} 22-23$ & & $025-026$ \\
A274a4 & $11.2 \mathrm{v} 29-30$ & & $032-033$ \\
A274a4 & $11.3 \mathrm{r} 1$ & 035 \\
A274a5 & $11.3 \mathrm{r} 4$ & & 038 \\
A274a6 & $11.3 \mathrm{r} 10-11$ & $11.3 \mathrm{r} 1$ & $044-045$ \\
A274a7 & $11.3 \mathrm{r} 18$ & $11.3 \mathrm{r} 9$ & 052 \\
A274a8-lost & & & \\
A274b1-lost & & & \\
A274b2 & $11.3 \mathrm{v} 7-8$ & $11.3 \mathrm{r} 27$ & $072-073$ \\
A274b3 & $11.3 \mathrm{v} 16-17$ & $11.3 \mathrm{v} 5-6$ & $081-082$ \\
A274b4 & $11.3 \mathrm{v} 21-22$ & $11.3 \mathrm{v} 11-12$ & $086-087$ \\
A274b5 & $11.3 \mathrm{v} 26-28$ & $11.3 \mathrm{v} 15-17$ & $091-093$ \\
A274b6 & $11.4 \mathrm{r} 1-3$ & $11.3 \mathrm{v} 20-23$ & $097-099$ \\
A274b7 & $11.4 \mathrm{r} 6-8$ & $11.3 \mathrm{v} 25-28$ & $102-104$ \\
A274b8 & & $11.4 \mathrm{r} 2$ & 110
\end{tabular}

In the following, the Old Uyghur text is treated first, because it is better preserved than the Tocharian A original.

\section{Transcription of the Old Uyghur Text}

The transcription of the Old Uyghur text given here is based on the MaitrSängim fragments, with restorations on the basis of the Qomul version and in part also the Tocharian A parallel. ${ }^{2}$ For transliterations of the separate fragments, see the publications by Israpil (in particular 2013) and Semet-Äysa (2015).

\section{Leaf 2 recto}

MaitrSängim (60TS001:5-1 recto) $)^{3}$

[lacuna of up to 14 lines]

001 ] ]L'R [anı] ešidip [ ] 15

002 [ ] br(a)hmayu bra[man] 1rk körü[m] 16

003 [yörü]r svapnaḍy(a)ne ulatı šast $a[\mathrm{r}] l[\operatorname{ar}$ g] 17

004 [u]kar bilir ärsär .. y(e)mä inčip ö[grünč] 18

005 sävinčtä ötrü ukmaz bilmäz kiši 19

\footnotetext{
${ }^{2}$ The parts marked in bold are restorations after MaitrQomul. The conventions of the transcription are those of Röhrborn (1977-1998).

${ }^{3}$ Compared to Israpil (2013, pp. 58-59), this fragment is to be reversed.
} 
006 osuglug kunčuyı br(a)hmavati hatun- 20

007 ka inčä tep teyür .. munadınčig 21

008 adınčıg tüllär körmišsiz hatunum 22

009 [ul]ug ögrünč[1]üg sävinčlig bol- 23

010 [tu]kum üčün tülüjüzni ojaru 24

011 [sa]kınu umadım .. yarın kün tuga tan 25

012 [yaruk]ınta tül yörgüči bram(a)nlarag 26

013 [kälürä]yin bo sizin kop kamag 27

014 [tınlıgla] $r \mathrm{ka}$ ațl(a)g mangal $<\mathrm{l}>$ ag tülü- 28

015 [nüzni yörä yar]lıkazunlar .. anı ešidi[p] 29

016 [säkiz tümän] tört mıy yinčg[ä] 30

017 [bram]a[nla]r ö[grünü]p sä[vinip] 31

\section{Leaf 2 verso}

MaitrSängim (60TS001:5-1 verso)

[lacuna of up to 14 lines]

018 [yagız] yer t[äpräd]i yinčül[üg]

15

16

019 [sävi]glig čäč[äk]lär birlä [ärdini]-

020 [lär] yagdı .. ulug küčlüg t[ägri]-

17

021 [lär] törtdün yınaktın turup

022 sizin karšı̀̇ıka yükünürlär

18

023 yer täprämäki y(e)mä takı sönmäz .

19

024 yıdlıg y(1)parl(1)g hua čäčäk yagar

20

025 t(ä)yrilärnin namo but k1lmak

21

026 ün eštilür .. a[n1] amtı biziø[ä]

027 ayu berin nä asıg tusu kut

028 kıv sizinä kälgälir .. uluš

029 balıktak1 t[1]nl(1)glarka y(e)mä

030 čog yalın kälgälir .. biz[inä]

031 [ye]mä kayu utmak yegädmäk [kälgälir]

032 [ö]girip sävinip br(a)hmayu p[urokit]

033 [inčä] tep [te]yür .. ančam [a ädgü]

034 [kälmä] $k$ a[nčama ]'D[ ]

[very short lacuna at most $^{4}$ ]
20

2

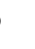

25

7

8

0




\section{Leaf 3 recto}

MaitrSängim (60TS1:005-1 recto) and

MaitrSängim (60TS001:5-2 recto)

$\mathrm{b}[\mathrm{ir}] \mathrm{y}(\mathrm{e}) \mathrm{g}(\mathrm{i}) \mathrm{rminč} \mathrm{üč} \mathrm{p(a)t(a)r} \mathrm{..}$

035 [olu]ruỵlar tözünlärim .. ötrü

036 br(a)manlar eliglärin örü kötürüp

037 ag(1)r ayag k1lıp käzigčä olurur-

038 lar külčirä yüzin br(a)hmayu-u

039 bram(a)n bram(a)n- $\odot$ lar tapa kö[rüp]

040 [inč]ä tep $\odot$ teyür .. adın

041 [a]dın muya- $\odot$ dinčig b(ä)lgü-

042 lär öni $\odot$ tözün küč-

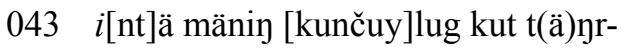

044 [i ärdinim] be[š t] örlüg ulug tül-

045 [lär körmiš ..] $a$ n $\iota$ amtı sizlär bahš1-

046 [lar k(ä)ntü k(ä)nt]ü ärdäminizlärni üntür-

047 [üp ol tülnüy] tüšin adırtlayu

048 [ber] $i[$ 引lär] .. kim [ka]mag yal(a)noklar

049 [eši]dzünlär .. mä[ni]n ögrünčün

050 [mäni]y yüräkim köylüm äsrük

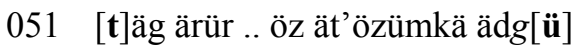

052 bolgusin $\mathrm{k}(\mathrm{a})$ ntüm sözläyin ..

053 muyadu adınu bram(a)nlar inčä tep

054 [t] eyürlär .. adınčıg tạlančıg bahšı-

055 nı̣ kunčuylug ärd(i)nisi tüllär

056 körmiš kim bolgay bo yer suvda

057 [o]l tülnün tüzü tükäti

058 [t]üšin sözlädäči .. inčip y(e)mä

059 [bi]z anča munča yıgvirag ayu

060 [berä]lim .. kayu ešilär tülintä

061 [kün] t(ä)Đri karnı̀a kirür tüšäsär

062 [ol eš]ilär bir uluš üzä ärkl[ig]

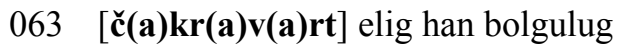

064 [ogul tugu]rur .. kayu ešilär $\mathrm{t}$ [ülintä]

065 [ay tän]r[i gr(a)]h[lar birlä karnınta]
01

02

03

04

05

06

07

08

09

10

11

12

13

14

15

16

17

18

19

20

21

22

23

24

25

26

27

28

29

30

31
A274a5

MaitrQomul, Leaf 3 recto;

A274a6

\section{Leaf 3 verso}

MaitrSängim (60TS1:005-1 verso) and

MaitrSängim (60TS001:5-2 verso) 
066 [k]irür tüšäsär .. ol ešilär t $\mathrm{t}[\ddot{o r r t}]$

067 [u]luš üzä ärklig č(a)kr[(a)v(a)rt elig] 02

068 han bo[lg]ulug ogul tugur[ur] ... . 03

069 kayu ešilär tülintä yigit [ur]1

070 [yaya] minip $\odot$ karnınta kirür 05

071 tül tüšäsär $\odot$ ol kunč[uylar] $\quad 06$

072 odgurat1 $\odot$ burhan č(a) $k$ - $\quad 07$

073 r(a)v(a)rt elig $\odot$ han bolgul[ug] 08

074 ogul tugurur .. amtı nä y(e)mä 09

075 taštın sınarkı b(ä)lgüläri[g nä] $\quad 10$

076 y(e)mä ičtin sıjarkı ad[Insıg] 11

077 adrok tüllärig kod[uru kolulasar] $\quad 12$

078 kečmädin ara siz[in yanıııta] 13

079 burhanl(1)g kün [t(ä))ri tugmakı] $\quad 14$

080 bolgay .. bo sava[g] ešidip ögir[ü] 15

081 sävinü br(a)hmayu bram(a)n iki el[igin] $\quad 16$

082 örü kötürüp $i$ nčä tep teyür .. anč $a$ [ma] 17

083 [mäy]i ančama ädgü asıg tusu an[ča]- 18

084 ma ädgü kut kıv kim mänin 19

085 ävimtä barkımta burhan kün $\quad 20$

086 t(ä)nri tugar ärmiš .... anta 21

087 ötrü br(a)hmayu prokid säkiz tümän 22

088 tört mın bram(a)nlar birlä 23

089 burhanka amranmakın br(a)hmava[ti] 24

090 hatunug ayayur agirlayurlar 25

091 tak1 y(e)mä ogul ugrınta ul[ug] 26

092 yagı̌̌ sačıg yagap bram(a)nla[rka] 27

093 ögdir anču berür .. anta [ötrü] 28

094 [t(ä))] rilär eligi hormuzta [täyri] 29

095 [tör]t maharač t(ä)pri[lärkä] 30

096 [inčä tep y(a)rlı]kayur .. siz[lär tözün]- 31

\section{Leaf 4 recto}

MaitrSängim (60TS1:005-2 recto)

bir y[egir]minč tört $\mathrm{p}(\mathrm{a}) \mathrm{t}(\mathrm{a}) \mathrm{r}$..

097 lär körüylär bo maitrillg kut 01

098 t(ä)nrisi burhan kutı küsüšin 02

099 tužit t(ä)yri yerin kodup b[r](a)hmav(a)ti 03

100 [hat]u[nn]un karanl[ag] tü[när]igin[tä] 04

101 [olur]ur näčä $\odot[\mathbf{y}(\mathbf{e}) \mathbf{m a ̈ ~ u l u g ]} 05$
A274b2

MaitrQomul, Leaf 3 verso

A274b3

A274b4

A274b5

A274b6 


\begin{tabular}{|c|c|c|}
\hline 102 & [küčl]üg $\odot$ t[(ä)ทrilär $]$ & 06 \\
\hline 103 & [tör]tdin $\odot$ yı̀a[k ayayu $]$ & 07 \\
\hline 04 & [agırlayu yükün]särlär .. [sizlär y(e)mä ] & 8 \\
\hline 05 & [barıp k(ä)ntü k(ä)ntü kuvragıjızlar] & 09 \\
\hline & [birlä tünlä küntüz tört] & 0 \\
\hline 07 & [yı̄aktın küyü küzädü barıłlar .. hor-] & \\
\hline 08 & [muzta t(ä)Đri y(a)rlıgın ešidip ögi-] & \\
\hline 09 & [rü sävinü tört maharač t(ä)Đrilär] & 13 \\
\hline 10 & [ärdinilig yarık kädip eliglärintä] & 14 \\
\hline & [bı bıčgu kılıč ur(u)ngu učrug yadıp] & \\
\hline & [k(ä)ntü k(ä)ntü kuvragları birlä öz (?)] & 17 \\
\hline & [yıjaklarınta turup bodis(a)v(a)tnın] & 8 \\
\hline & [anasına yäk ičkäk yik yilpik] & 15 \\
\hline & [yavlak sakıntačı yakın tägmäz-] & 20 \\
\hline & [ün tep kop adadın küyü] & ( \\
\hline 17 & [küzädü ärürlär .. anta] & \\
\hline
\end{tabular}

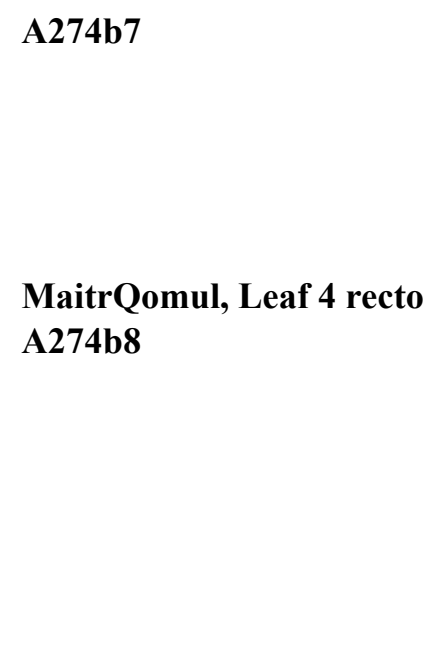

\section{Translation of the Old Uyghur Text ${ }^{5}$}

001 Having heard [this], ... 002-007 the brahmin Brahmāyu, even though he knows (lit. explains) fortune-telling and understands ${ }_{2}$ the svapnadhyaya ("interpretation of dreams") and other śāstras, says to his wife, the queen Brahmāvatī, as a person ignorant 2 out of joy ${ }_{2}$, the following: 007-008 "Wonderful ${ }_{2}$ dreams have you seen, my queen! 009-011 Because of my being very joyful ${ }_{2}$, I could not interpret (lit. think) your dream(s) correctly. 011-013 Tomorrow, at sunrise, at dawn, I will [call] dreaminterpreting brahmins. 013-015 They may interpret your dream(s), (which are) auspicious $_{2}$ for all $_{2}$ beings." 015-017 Having heard this, the [8]4,000 fine brahmins were glad ...

[lacuna of up to 14 lines]

018 “... the [grey] earth trembled. 018-020 A [jewel] rain with lovely pearl flowers rained down. 020-022 Great and mighty gods rise from the four directions and bow before you. 023 And also the trembling of the earth does not stop. 024 Fragrant ${ }_{2}$ flowers rain down. 025-026 The voices of the gods saying (lit. making) "namo buddha" are heard. 026-027 Now say this to us: 027-028 What profit 2 and power $_{2}$ are about to come to you? 028-030 And (what) splendour ${ }_{2}$ is about to come to the beings in the towns 2 ? 030-031 And which success [is about to come] to us?" 031-032 Being glad Brahmāyu the purohita says: "O such [a good coming]! ...

[very short lacuna at most]

"In the translation of the Old Uyghur text, the subscript "2" denotes a hendiadys in the original, i.e., a single concept expressed by two words in Old Uyghur. 
035 Sit down, my noble ones!" 035-038 Then the brahmins raise up their hands, make profound reverence and sit down in a row. 038-040 With smiling face the brahmin Brahmāyu looks to the brahmins and says: 040-045 "[By] the different noble power of various wonderful signs my glory of a [great princess], my divine [jewel, has seen] fivefold great dreams. 045-049 Now, you teachers, muster your own skills, and please explain the portent of this dream 2 , so that all beings may [hear]! 049-051 Out of joy my heart $_{2}$ is as if drunk. 051-052 I myself want to tell [about] the well being of myself." 053-054 Surprised $_{2}$ the brahmins say: 054-056 "The jewel of a princess of the excellent teacher has seen dreams. 056-058 Who on this earth might it be who (could) fully express the portent of that dream? 058-060 And may we tell something in short: 060-064 Which woman dreams in her dream that the sun enters into her belly, this woman [gives birth to a child] who will become cakravartin king with power over a country. 064-068 Which woman dreams in her dream that [the moon with the planets] enters [into her belly], this woman gives birth to a child who will become cakravartin king with power over four countries. 069074 Which woman dreams in her dream that a boy 2 riding on an [elephant] enters into her belly, this princess certainly gives birth to a child who will become a Buddha cakravartin king. 074-080 Now, if one thinks intensively about the outer signs as well as the wonderful ${ }_{2}$ inner dreams, (they mean that) immediately the birth of the Buddha sun-god will take place on your side." 080-082 Having heard these words, the brahmin Brahmāyu rejoices, raises up both his hands, and says: 082-086 "Such happiness, such good profit 2 , such good power $_{2}$ that - as it turns out - the Buddha sun-god is being born in my home 2 ". 086-090 Thereupon the purohita Brahmāyu together with the 84,000 brahmins reveres 2 the princess Brahmāvatī out of love for the Buddha. 091-093 And because of (his) child, he makes a great sacrifice 2 and gives the brahmins a reward ${ }_{2}$.093-096 Thereupon Indra, the king of gods, graciously says to the four Mahārāja gods: 096-097 "Look, o noble ones! 097-101 In the wish for the Buddha dignity this maitri god of glory leaves the divine land of the Tusita (heaven) and sits down in the darkness of the belly of princess Brahmāvatī. 101-107 No matter how many great powerful gods from the four directions may bow (for him) in reverence 2 , you too go and protect $_{2}$ (him) continuously by day (and) by night from the four directions." 107-117 Having heard the order of god Indra, the four Mahārāja gods rejoice 2 , put on (their) jewel armour, [holding] knives 2 and swords in their hands they spread out banners 2 , stand each with their own retinues in their own regions (lit. directions), and in order that no vampire , demon $_{2}$ or evil thinker comes close to the mother of the Bodhisattva, they are protecting from all dangers.

\section{Notes to the Old Uyghur text}

003 [yörü]r is restored after Uyg. yörgüči in 012 of this fragment. Israpil $(2013$, p. 61) reads [bilmä]z.

003 šast $a[\mathrm{r}] l[\operatorname{ar} 1 \mathrm{~g}]:$ Israpil reads šast[arlar], Semet- Äysa (2015, p. 230) read šas$\mathrm{t}[\mathrm{ar}] l[\mathrm{ar}]$. However, the verb $u k$ - requires an accusative $(-X g)$, for which there seems to be enough space. 
010 tülünüzni: The $\mathrm{y}$ of the transcription is written defectively: instead of $\langle\mathrm{NK}\rangle$, it is written only with $<\mathrm{K}>$. Here and in the following, this spelling is indicated with a dotted velar nasal $\dot{\mathrm{y}}$. On this peculiarity, typical for MaitrSäng, see Laut (1986, pp. 71-74). Cf. further karšı̀̇ıka 020 and [olu]rujlar 035.

011 [sa]kınu: The facsimile preserves [ ]QYNW; Israpil (2013, p. 61) reads QSYNW.

011 tuga: This word was added later. Israpil (2013, p. 61) and Semet- Äysa (2015, p. 230) read kün burnı tuga 'at early sunrise'. The expression with burnı also occurs in Old Uyghur, but here we have only kün tuga 'at sunrise'. The expression kün tugmak 'rising of the sun' (lit. 'being born of the sun') is found also in Modern Turkic languages.

012 The restoration is uncertain.

012 yörgüči: So read after Israpil (2013, p. 61); not with Semet-Äysa (2015, p. 230) yörgüsi.

013 [kälürä]yin: Alternatively, [okuya]yın 'I will call' would also be possible.

017: Israpil (2013, p. 61) reads [ ]'[ ]R 'WY[ ]P S'[ ].

018 [yagiz] yer: Restored after Tocharian A tkam 'earth' A274a2.

018 t[äpräd]i: Restored after Tocharian A mey $\bar{a}$ 'trembled' A274a2. Israpil reads t[äprämäk]i (2013, p. 61).

018 yinčül[üg]: Restored after Tocharian A wroki ‘pearls’ A274a2.

019 [sävi]glig: Restored after Tocharian A ciñcram 'lovely’ A274a2.

019-020 [ärdinilär]: There is no space at the beginning of the line for [yagmur], pace Israpil (2013, p. 60) and Semet- Äysa (2015, p. 231).

027 nä 'what': This word occurs at the beginning of this clause, but has to be understood at the beginning of the next clause as well.

031 [kälgälir]: There is enough space for this restoration. Israpil (2013, p. 60) reads [kälir?]; the word is lacking in Semet-Äysa (2015, p. 231).

033-034 In view of the Tocharian A parallel ote täprem praștā śämlune 'o what a timely coming', perhaps something like ančam[a ädgü kälmä]k 'o such a good coming' has to be restored instead of anč[ama mäyi ančam]a ä[dgü] in Semet- Äysa (2015, p. 231). Since ančama is always repeated, this word was probably following as well.

044-045 b[eš t]örlüg ulug tül[lär]: MaitrQomul reads [beš] törlüg ulug törlüg tü[1]lär (Geng-Klimkeit-Laut 1988, p. 322). The second törlüg must be a scribal mistake, a case of dittography, due to the fact that the beginning of the following tü[l]lär is identical.

045 [körmiš]: This restoration is to be preferred to [kördilär] in Semet-Äysa (2015, p. 232) because the king has not had this dream himself, but tells what he has heard about his wife's dream.

052: If the Tocharian A text is read correctly and sözläyin corresponds to (w)eñim 'may I say' A274a7, a real object is expected; (w)eñim is never used in the way suggested by the translation of Semet-Äysa (2015, p. 239): “[...], will ich selbst (damit) sagen." 
052 k(ä)ntüm: For the Qomul version, Geng-Klimkeit-Laut (1988, p. 322) read kntü qiltï; instead, the Qomul version is probably to be read k(ä)ntü kaltı, but the exact function of kaltı, normally 'as', remains unclear to us here.

056-058: For the translation, see Erdal (2004, p. 276).

060 tülintä: Is lacking in the Qomul version.

061 karnına: The Qomul version has instead of this dative the locative karnınta. See also line karnınta 070.

062 [eš]ilär: This plural form is probably used for politeness and does not denote a plural as in Semet-Äysa (2015, p. 239).

065 karnınta: So restored after the Qomul version, but karnına would also be an option; cf. karnina 061 vs. karnınta 070.

068, 073 bolgulug: This interpretation as adjective fits the context better than a noun bolguluk as per Israpil (2013, p. 55) and Geng-Klimkeit-Laut (1988, p. 322).

072-073 č(a)kr(a)v(a)rt: Israpil (2013, p. 55) reads č[akra]virt.

076-077 ad[1nsig] adrok: The Qomul version reads [a]dınsig adrok adrok (GengKlimkeit-Laut 1988, p. 322 read and restored instead [blgülärig] ạdruq ạdruq); adrok literally means 'various', but with adınsig it forms a binome, 'wonder$\mathrm{ful}_{2}$.

080-081 ögir[ü] sävinü: sävinü requires the restoration ögir[ü]. Qomul has instead ögi[r]ip sävin(i)p.

082-086: For the translation, see Erdal (2004, p. 274).

090 ayayur agtrlayurlar: The English translation requires a singular, but in Old Uyghur the verb is in the plural.

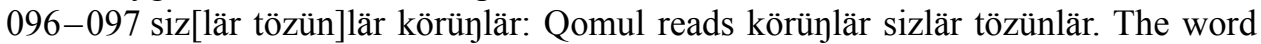
order of the Qomul version matches that of the Tocharian A pälkāc klyomäs A274b6.

097 maitrilig: The Tocharian A version has metrakșim 'belonging to Maitreya' A274b6, but the Old Uyghur has to be interpreted as 'provided with maitri (benevolence)'.

097-098 maitrilig kut $\mathrm{t}(\mathrm{a})$ yrisi: In the Old Uyghur text, this is the subject of the following sentence, while the corresponding Tocharian A metrakșim paräm-ñkät 'Maitreya god of glory' A274b6 is the object of the preceding pälkāc 'see!'.

106 [tünlä küntüz] 'by night (and) by day': The order is reversed in Tocharian A ykom o(señi) 'by day (and) by night' A247b7.

\section{Transliteration of the Tocharian A Fragment A274}

Of the Tocharian A fragment A299 the original is now missing. A photo is contained in the plates volume of the edition (Sieg-Siegling 1921b, p. 45), but a little piece at the right was attached to the fragment later so that it is missing on the photo. On the basis of this photo, no important new manuscript readings can be made and therefore a separate transliteration of this fragment is not given. However, the other fragment, A274, has been preserved and compared to the edition of Sieg-Siegling (1921a, 
p. 143) some small corrections and additions have been made. In particular, traces of lines a7 and b2, which according to Sieg and Siegling were completely lost, do in fact remain. ${ }^{6}$

a1 /// ktaña $、 m \cdot h a ̄ b r a m-n ̃ a ̈ k t a c c ~ o k i ~ p u r o h i t a ̄ n a c ~ k a k m u \underline{a n s ̦ ~}$

a2 /// cu [pa]rkar wākmtsaṃ șotreyntu : meyā tkam svawra wroki ciñcram śla pyā

a3 $\quad / / / \cdot \mathrm{m} \cdot$ buddha rake klyoștara $、$ ātsats ñäktaśśi : pākșiñm-ā-m knașși ku

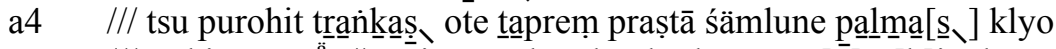

a5 I// - rki șmeñc ${ }^{a-\alpha}, \|$ smimāṃ akmalyo brahmāyu p[u]

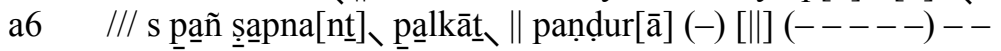

a7 $/ / /----\cdot$ eñi $[\underline{m}], / / I$

b2 $/ / /-(-)[\mathrm{c}] \cdot[\mathrm{k}] \mathrm{kr} \cdot \mathrm{v} \cdot \mathrm{t} \cdot-$ yata $[\mathrm{r}]_{(\mathrm{N})}(-)-/ / /$

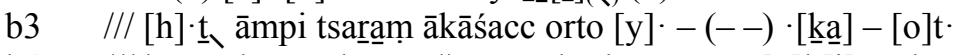

b4 /// koṃ-ñkat parkatarar || țmaș

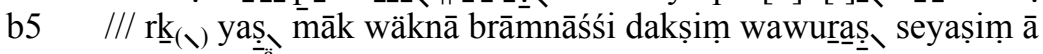

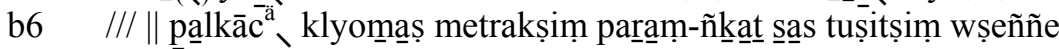

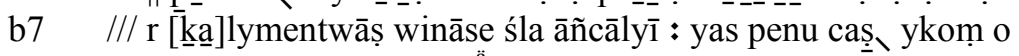

b8 /// [ā]kāl șeș țmaș

\section{Transcription of the Tocharian A Text}

A299

a8 /// || || sās nu tāpärk plāc jambudvipaṃ ywārckā parnoreyo yetusāṃ ketumati rīyaṃ kärsnāl(y)i ///

b1 /// (bra)hmna-purohituneșināp pram-ñäktes waṣtwam • śtwar-ñemintwāṣim täpräṃ ștānkaṃ śtärc mañis okät tyo ///

b2 /// p prāmne śnu • brahmavatiṣiṃ śriñnääktes kātsạ̣ cmolu nutässi cmol eṃtsäștär || haṃsavānik(ạ̣ ||) ///

b3 /// (po)ñcäṃ dvipam ! wroki suk lkātsi p pis mosạ̣ : [1b] ñäkcyāñ rapeyu ! nusenc kälnīñc puk käly(m)e(yu :) [1c]

b4 /// lyo : [1d] āṣānikāṃ kāruṇikāṃ ! bodhisatvāṃ kātsạ̣ lmont cam ! klyomänt metrakäm : $1 \| / / /$

b5 /// (c)m(o)l wärporäṣ päñ śāwam șäpnant lkāṣ täm ṣu〈rma)ṣ temi puk marmsạ̣ suk (kä)ly(tär) ///

${ }^{6}$ The conventional symbols for Tocharian are used: - illegible akșara; · illegible or missing part of an akșara; 、 virāma; [ ] uncertain reading; ( ) restoration; = sandhi; $\odot$ string hole space; : punctuation in the original manuscript; \langle\rangle addition against the manuscript; $;$ caesura in metrical passages (not in the original manuscript). In the transcription of verse passages, pāda numbers in [ ] are added after the relevant pāda against the manuscript. In the translation, square brackets denote additions that are required to make the text more readable. 
b6 /// ṣ wāwrus tmäk sām tsopatsäṃ kāckeyo lakeyạ̣ orto ṣmäṣ täm pälkorä(ṣ) I/I

b7 /// (trä)nnkäṣ kus șurm klyomim sne praṣt lakeyạ̣ orto lymāṣt || kātkmāṃ nāṃtsus brahmāvati tränkäș kācke pa(r)s(ā)r klyom añumāski ///

b8 /// (smi)māṃ akmalyo brahmāyu puro(hit trän̉kä)ṣ peṃ klyomị̣ mänt wäknā pälkāte || brahmāvati träṅkäṣ || sundaravānikaṃ || ś · oki ///

- lacuna of about 10 lines -

\section{A274}

a1 /// (ñä)ktañ m(a)hābram-ñäktacc oki purohitānac kakmuräṣ

a2 /// (nak)cu parkar wākmtsạ̣ șotreyntu : [1b] meyā tkạ̣ svawrä : wroki ciñcrạ̣ śla pyā(ppyā̃̃) [1c]

a3 /// (:) [2a] $\left(\mathrm{n}_{\ddot{a}}\right) \mathrm{m}(\mathrm{o})$ buddha rake käșṣi

a4 /// (kātkmāṃ nāṃ)tsu purohit tränikäṣ ote täpreṃ praṣtā sämlune pälmäs klyo(mäṣ)

a5 /// (lyukrā sä)rki ṣmeñc || smimāṃ akmalyo brahmāyu purohit brā(mnāsac lkāmāṃ tränikäṣ)

a6 /// s päñ ṣäpnant pälkāt || paṇụuā(ṅkaṃ) ||---- - - ///

a7 ///----(w)eñim ///

b2 /// - - c(a)kkr(a)v(art)t(i) - yatär ///

b3 /// (puro)h(i)t āmpi tsaräṃ ākāśacc orto y• - - (träni)kä(ṣ) ot(e täpreṃ)

b4 /// koṃ-ñkät pärkatär || tmäṣ brahmāyu purohit okät tmāṃ (śtwar wälts)

b5 /// (yä)rk yaș māk-wäknā brāmnāśśi dakșiṃ wawuräṣ seyașiṃ ā(kāl)

b6 /// || pälkāc klyomäṣ metrakșim paräṃ-ñkät säs tuṣitṣiṃ wṣeññe

b7 /// (śtwa)r kälymentwāṣ wināse śla āñcālyī : yas penu caṣ ykoṃ o(ṣeñi)

b8 /// ākāl șeṣ tmäṣ poñś || aptsaradarśạ̣ || wasu(ṣ)

\section{Translation of the Tocharian A Text}

\section{A299}

a8 ... || || This conversation is to be understood [as taking place] in the middle of Jambudvīpa, in the town Ketumatī, adorned with splendour. ...

b1 ... in the houses of the Brahmā-God of the brahmin purohitaship, in the high palace with four [kinds of] jewels, (on the) eight[h] (day) of the fourth month

b2 ... the wives of a brahmin. In order to make the births disappear, he takes birth in the womb of the Śrīdeva of a Brahmāvatī. || in the hamsavāinkam [tune] || 
b3 ... On the whole continent pearls (rain down), pleasant to look at for all. Divine instruments sound loudly, all directions resound. ...

b4 ... the honourable, compassionate Bodhisattva, the noble Maitreya, who is staying in the womb. 1.

b5 ... having received the birth, she sees five great dreams. For that reason happiness stands in all her veins ...

b6 ... woken up from [her] (sleep?) she is sitting full of great joy straight up in her bed. Having seen that, ...

b7 (Brahmāyu the purohita) says: "What [is] the reason, o noble one, [that] you have seated yourself straight up before the [right] time?" Joyful Brahmāvatī says: "Be glad, o noble one! A wonderful (thing I have seen in my dreams)."

b8 With smiling face Brahmāyu the Purohita (says): "Say, o noble one! In which way have you seen [that]?” Brahmāvatī says: || in the sundaravāinkam [tune] \| "Like ...

- lacuna of about 10 lines -

\section{A274}

a1 When (the brahmins) had come to the purohita as the gods to the god Mahābrahmā,...

a2 “... (last night) the excellent signs have arisen: The earth trembled, pearls rained down together with lovely flowers ...

$\sim$ Uy.018-020

a3 ... The word '(praise) to the Buddha' of a mass of gods is heard. Tell us, o teacher! What ..."

$\sim$ Uy.025-026

a4 (Being glad) the purohita says: "Oh! What a timely coming! Sit down, o noble ones!"

$\sim$ Uy.032-035

a5 ... (the brahmins) sit down one after the other. With smiling face Brahmāyu the purohita (says looking to) the brahmins ...: “...

$\sim$ Uy.038

a6 (My wife) has seen five dreams. || in the paṇurāinkam [tune] (\|)

$\sim$ Uy.044-045

a7 ... may I say ..."

$\sim$ Uy.052

b2 ... cakravartin king ...

$\sim$ Uy.072-073

b3 (Brahmāyu) the purohita (raised) both his hands up to the sky (and) says: "O (such) ...

$\sim$ Uy.081-082

b4 ... the sun-god arises." || Thereupon Brahmāyu the purohita (honours together with) the 8(4),000 (brahmins Brahmāvatī) ... 
$\sim$ Uy.086-087

b5 ... when he had given the brahmins gift[s] in many ways, ... wish for a son ... $\sim$ Uy.091-093

b6 ... "See, o noble ones, the Maitreya god of glory! He (gives up) [his] place in the Tușita [heaven] (in the wish for the Buddha worth) ...

$\sim$ Uy.097-099

b7 ... (no matter how many gods) from the four directions honour (him) with [their] hands put together, you too (must protect) him by day [and] by night ..." $\sim$ Uy.102-104

b8 $\quad \ldots$ had the wish ... Then ... all $\|$ in the aptsaradarśam [tune] $\|$... wearing ... $\sim$ Uy. 110

\section{Notes to the Tocharian A Text}

\section{A299}

b1 (bra)hmna-purohituneșināp pram-ñäktes 'of the Brahmā-God of the brahmin priesthood': This metaphor certainly refers to the excellent brahmin priest Brahmāyu (cf. A299b8). For similar metaphors, compare for instance Tocharian B pūdñäkteșse twe bram-ñäkte 'you [are] a Brahmā-God of a Buddha' SI P/1a1 (Pinault 2008, p. 302) or Tocharian A säm metrakși bram-ñkät 'this BrahmāGod of a Maitreya' YQII.10a2 (Pinault 2003, pp. 51-52, and passim). Nicely parallel is in particular Tocharian A (brämnune)și bram-ñkät YQII.4a2+A212a3 and brāmnu(neși bram-ñkät) YQII.6a3 'Brahmā-God of brahminhood' (Pinault 2003, p. 50).

b1 okät tyo ///: Since this is a reading by Sieg-Siegling (1921a, p. 158) from the fragment that was attached later, after the photo of the plates volume was made, it cannot be verified and an interpretation is difficult. One would rather expect okät kom 'day eight' or oktäñä̈m kom 'on the eighth day'. After a suggestion by Georges-Jean Pinault (p.c.), one may also consider a reading okätt y $(k) o(m)$ '[on day] eight, by day'.

b2 brahmavatișim śriñ̃äktes 'of the Śrīdeva of a Brahmāvat̄̄': A metaphor to express that Brahmāvatī is like Śrīdeva, the goddess of love, among women.

b2 cmolu nutässi: The position of this final clause is surprising, but a reading 'In order to make the births disappear in the womb of the Śrīdeva of a Brahmāvatī, he takes birth' can be excluded.

b2 hamsavāinkam: Name of a tune with 5 lines $(4 \times 5,8+8,8,5$ syllables $)$. Usually, strophes contain direct speech, but in this case it is not clear who is speaking. Probably a divine voice is heard commenting on the events on stage.

b3 suk lkātsi 'pleasant to look at': For this phrase, literally 'happiness to see', 'to see happiness' etc., cf. Thomas (1954, pp. 744-745). For the finite verb of the sentence, Georges-Jean Pinault (p.c.) convicingly suggests 'rain down', i.e. swiñc. 
b4: The whole pāda 1e is a nominal phrase in the oblique case: it must be the object of a verb that was preceding in pāda $1 \mathrm{~d}$.

b5: Here and in the next line the subject is Brahmāvatī.

b5 (kä)ly(tär): This restoration, possible according to the traces preserved, follows a plausible suggestion of Georges-Jean Pinault (p.c.).

b7: The translation by Thomas (1957, p. 215) is not exact: "Was [ist] los [wörtl. die Ursache], o Edle? Vor der Zeit sitzest (Prät.) du [ja] aufrecht auf [deinem] Lager!"

b7 kācke pa(r)s(a) r: Literally 'cause joy!', 'evoke joy!'. For this expression, cf. pūk $k \bar{a} c k e$ parsāc A217 a4. The restoration follows Schmidt (1974, p. 333).

b8 sundaravāinkam: Name of a tune with possibly $4 \times 6,6,5$ syllables. The strophe must have continued on the following leaf, which is unfortunately lost.

b8 $s^{\prime}:$ Sieg and Siegling (1921a, p. 159) propose to restore to śäm) 'woman'. Although oki 'as' normally causes a preceding consonant to be geminated, so that one would have expected śänn oki or śämn oki, this restoration is possible, since plain anusvāra as we would have here is also found. However, it is a little doubtful whether the required three dots $(<\ddot{a}>$ plus $<m>)$ should not have been a little more visible. A daring but attractive alternative solution that starts from a more plausible reading $<$ Ś[i] $>$ is suggested to us by Georges-Jean Pinault (p.c.). According to him, the context suggests a beginning of the poem of the type "The sun entered as it were into my belly". The form śi could be the 3sg.prt. of a verb s'äy $\bar{a}$ - 'enter' otherwise represented by the hapax legomena inf. śināssi A399a6 and prt.ptc. śaśyu A69a2 (Peyrot 2013, pp. 825826).

\section{A274}

a2-3: These lines are metrical. The metre has $4 \times 5,7$ syllables. Brahmins who have observed auspicious signs have come to Brahmāyu to ask him about that.

a2 'cu: Only cu 'you' or nakcu 'last night' are possible restorations. The latter fits the context perfectly, although no Old Uyghur parallel is preserved for this phrase.

a3 $\left(n_{\ddot{a}}\right) m(o)$ : A restoration to $(n a) m(o)$ buddha after Old Uyghur namo but 025 is not possible, because $<\mathrm{m}>$ is the second element of a ligature. However, as it can hardly be any other word, we might here have a rare variant $n_{\ddot{a}} m o$ (if not simply $n m o$ ) of the expected namo, written $<\underline{\mathrm{n}}_{\underline{a}} \mathrm{mo}>$. The monosyllabic variant $n_{\ddot{a}} m o$ is required also by the metre.

a3: The pāda end mark in the middle is probably that of $2 \mathrm{~b}$. It is not likely to be of $2 \mathrm{c}$ because then only one line would be left to correspond to the Old Uyghur lines 026-030, which are more likely to take up two pādas.

a3 klyoștär ... ñäktaśśi 'is heard of the gods': The genitive is ambiguous and could also denote the agent of the passive, cf. Schmidt (1974, p. 255): "wird von(?) den Göttern ... gehört". As the brahmins are speaking, the former, possessive interpretation is preferable, and it is confirmed by Old Uyghur t(ä)yrilärnī ... kllmak ün eštilür 'the voice of the gods saying [lit. making] ... is heard' 025- 
026. However, it should be noted that one would have expected $t(\ddot{a})$ yrilärni ... üni 'the voice of the gods'.

a3 ätsäts: This word is translated as 'thick, dense' by Carling (2009, p. 59b), but she does not list this occurence. Schmidt (1974, p. 255) notes that that meaning does not fit the context here. However, it may refer to a "density" of gods, i.e. a large number of gods.

a3 pākssiñ $\{\tilde{n}\}-\bar{a}-m$ : The edition has an incomprehensible pākșin māmkäs și (SiegSiegling 1921a, p. 143). With Carling (2009, p. 30b), the correct reading must be pākșiñn-a-a $m$ käsși, with a correction of the akșara $<\tilde{n} m \bar{a}>$ to $<\tilde{\mathrm{n}}\{\tilde{\mathrm{n}}\} \overline{\mathrm{a}}>$. The unsuffixed imperative pākssiñ 'tell!' does occur (A54b5, YQIII.12b2), but the suffixed variant is much more frequent: mostly we find $p \bar{a} k s \underline{i n \tilde{n}}-\bar{a}-\tilde{n} i$ 'tell me!'. The expected pl. suffix pākșiññ-a- $-m$ 'tell us!' is nicely confirmed by Old Uyghur biziyä ayu beriy 'id.' $026-027$, so that a correction of the text as proposed by Carling is perfectly warranted.

a4: Brahmāyu is surprised that the brahmins, whom he just wanted to call for, have already come to him by themselves.

a5 (sä)rki: The word särki by itself means 'after, following'. Although this is not impossible in the context, it was most probably preceded by lyukrā: the phrase lyukrā särki means 'closely following, step by step, gradually' (cf. Skt. anupadam), which fits the Old Uyghur parallel käzigča 'in a row' 037.

a5 brā(mnāsac lkāmām tränkäs): The restoration is based on the Old Uyghur parallel br(a)manlar tapa körüp [inč] ä tep teyür 'looks to the brahmins and says'. For this expression, cf. āmāśāsac pälkoräs tränkäs 'looking to the ministers he says' A342a1, bodhisatvānac lkāmām (tränki) ñc 'looking to the Bodhisattva they say' A257a5.

a6 panduränkam: The metre of this tune is unknown. The tune ñikci-pandurāinkam 'divine pandurānkam' has the metre $4 \times 5,7$, but the two tunes need not have identical metres.

b3 orto $y$ : The restoration is uncertain. orto cacluräs 'having raised' or orto cacäl 'raised' would fit the context; cf. tsar orto cacluräs 'having raised [his] hand' YQI.4b1 and pācinäs tsaräm orto cacluräs 'having raised [their] right hands' YQII.2b5. However, even though $[c] \cdot$ cannot be completely excluded, the first character is more probably $[y]$. (as it is transliterated and transcribed here). Another, more serious obstacle to reading cacluräs is that the lower part of the large second akșara $c l u$ should have been visible, while it is not.

b4 okät tmām (śtwar wälts) '84,000': Completed after Old Uyghur säkiz tümän tört min '84,000' 087-088.

b5 $\bar{a}(k \bar{a} l)$ 'in the wish': The restoration is uncertain, because his wish for a son will certainly be fulfilled. Perhaps the context was something like 'because of the fulfilling of his wish for a son'.

b8 aptsaradarśam: Name of a tune with $4 \times 7 ; 7$ syllables. 


\section{Glossary}

In many cases it was difficult to decide how the glossary should be arranged, as the word correspondences are often not one-to-one. We have tried in each case to base our decision on practical considerations. Words that are completely restored in either Old Uyghur or Tocharian A are not included. However, restorations of the Old Uyghur Sängim version on the basis of the Qomul version are included. In Old Uyghur fixed expressions, parts without correspondence in Tocharian A are underlined.

\section{Tocharian A-Old Uyghur Glossary}

akmalyo (ins.sg.) 'with ... face' A274a5

$\bar{a}(k a ̄ l)$ ? 'wish' A274b5

āñcālȳi see wināse śla āñcālyī

āmpi 'both' A274b3

okät tmāṃ (śtwar wälts) '8(4),000'

A274b4

ote täprem 'o such' A274a4

ot(e täprem) 'o such ...!' A274b3

orto $\mathrm{y}$ - '(putting) up' A274b3

o(șeñi) 'by night' A274b7

(kātkmāṃ nāṃ)tsu (prs.ptc. + prt.ptc.)

'being glad' A274a4

kälymentwāṣ (abl.pl.) 'from the directions' A274b7

$\mathrm{ku}(\mathrm{s})$ 'what' A274a3

koṃ-ñkät 'sun-god' A274b4

klyo(mäṣ) (nom.pl.m. as voc.) 'o noble ones' A274a4

klyomäṣ (nom.pl.m. as voc.) 'noble ones' A274b6

klyoștär (3sg.prs.mid.) 'is heard' A274a3

c(a)kkr(a)v(art)t(i) 'cakravartin' A274b2

ciñcram (pl.f.) 'lovely' A274a2

ñäktaśśi (gen.pl.) 'of the gods' A274a3

täprem see ote täprem

tuṣitșim 'belonging to the Tuṣita

(heaven)' A274b6

tkam 'earth' A274a2

tmāṃ see okät tmāṃ (śtwar wälts)

tmäṣ ‘thereupon' A274b4 yüzin (ins.sg.) 'with ... face' 038

ugrinta 'because of' 091

iki 'two' 081

säkiz tümän tört mı ‘8(4),000’ 087-088

ančam[a] 'such' 033

anča[ma] 'o such ...!' 082

örü kötürüp (cvb.) 'raising up’ 082

[tünlä] 'by night' 106

[ö]girip sävinip (cvb.) 'being glad $_{2}$ ' 032

yına[k] 'direction’ 103

nä 'what' 027

burhan kün t(ä)pri 'Buddha the sun-god' 085-086

tözünlärim (pl.-1sg.poss.) 'my noble ones' 035

siz[lär tözün]lär (pl.) 'you noble ones'

096-097

eštilür (3sg.aor.) 'is heard' 026

č(a)kr(a)v(a)rt elig han 'cakravartin king' 072-073

[säv]iglig 'lovely' 019

t(ä)yrilärnin (gen.pl.) ‘of the gods' 025

tužit 'Tuṣita (heaven)' 099

[yagız] yer '[grey] earth' 018

anta ötrü ‘thereupon’ 082 
tränkäṣ (3sg.prs.) ‘says’ A274a4

dakșim 'gift' A274b5

nāṃtsu see (kātkmāṃ nāṃ)tsu

$\left(\mathrm{n}_{\mathrm{a}}\right) \mathrm{m}(\mathrm{o})$ 'praise' A274a3

paräṃ-ñkat 'god of glory' A274b6

pākșiñ $\{\tilde{n}\}$-ā-m (sg.ipv.-pl.suff.) 'tell us!' A274a3

päñ 'five' A274a6

pärkatär (3sg.prs.) 'rises’ A274b4

pälkāc (ipv.pl.) 'see’ A274b6

pälmäs (pl.ipv.) ‘sit down!' A274a4

purohit 'purohita' A274a4

(puro)h(i)t 'purohita' A274b3

purohit see also brahmāyu purohit

penu 'also' A274b7

pyā(ppyāñ) 'flowers' (nom.pl.) A274a2

buddha 'Buddha' A274a3

brahmāyu purohit 'the purohita

Brahmāyu' A274a5

brahmāyu purohit 'Brahmāyu the purohita' A274b4

brāmnāśśi (gen.pl.) 'to the brahmins'

A274b5

brā(mnāsac) (all.pl.) 'unto the brahmins' A274a5

metrakșim 'belonging to Maitreya'

A274b6

meyā 'trembled' (3sg.ipf.) A274a2

yaș see (yä)rk yaș

yas (pl.) 'you' A274b7

(yä)rk yaṣ (3sg.prs.) 'honours' A274b5

ykom ‘by day' A274b7

rake 'word' A274a3

(lyukrā sä)rki 'one after the other' A274a5

wawuräs (abs.) 'having given' A274b5

wasu(s) (prt.ptc. nom.pl.m.) 'having put on' A247b8

wināse śla āñcālyī (3pl.prs.-sbj.) 'honour with [their] hands put together' A247b7 inčä tep [te]yür ( cvb. + 3sg.aor.) 'says so' 033

ögdir anču 'gift 2 ' 093

namo 'praise' 025

kut t(ä)nrisi 'god of glory' 097-098

bizin[ä] ayu berin 'tell us!' 026-027

be[š t]örlüg 'fivefold' 044

tugar ärmiš 'is being born - as it turns out' 086

körüylär (ipv.pl.) ‘look’ 097

[olu]ruylar (2pl.vol.) 'sit down' 035

br(a)hmayu p[urokit] 'the purohita

Brahmāyu' 032

br(a)hmayu bram(a)n 'the brahmin

Brahmāyu' 081

[y(e)mä] 'also' 104

čäč[äk]lär (pl.) 'flowers' 019

but 'Buddha' 025

br(a)hmayu bram(a)n 'the brahmin

Brahmāyu' 038-039

br(a)hmayu prokid 'Brahmāyu the purohita' 087

bram(a)nla[rka] (dat.pl.) 'to the brahmins' 092

bram(a)nlar tapa 'to the brahmins' 039

maitrilıg 'provided with maitrī

(benevolence)' 097

t[äpräd]i 'trembled' (3sg.prt.) 018

[sizlär] (pl.) 'you' 104

ayayur agirlayurlar 'revere' 2090

[küntüz] 'by day' 106

ün 'voice' 026

käzigčä 'in a row' 037

berür (3sg.aor.) 'gives' 093

[kädip] (cvb.) 'having put on' 110

[ayayu agırlayu yükün]särlär (3pl.cond.)

'bow in reverence, ${ }_{2}$ 103-104 
(w)eñim (1 sg.opt.) 'may I say’ A274a7 wșeññe 'place' A274b6

śämlune 'coming' A274a4

(śtwa)r 'four' A274b7

śla 'with' A274a2

śla see also wināse śla āñcālȳi șäpnant (pl.) 'dreams' A274a6 șmeñc (3pl.prs.) 'sit' A274a5

särki see (lyukrā sä)rki

seyașim 'belonging to a son' A274b5 smimāṃ (prs.ptc.) 'smiling' A274a5 svawrä (3pl.ipf.; for sawrä) 'rained down' A274a2 tsaräṃ (nom.obl.du.) ‘hands’ A274b3

\section{Old Uyghur-Tocharian A Glossary}

agırlayurlar see ayayur agırlayurlar anča[ma] 'o such ...!' 082 ančam[a] 'such' 033 anču see ögdir anču anta ötrü 'thereupon' 082 [ayayu agırlayu yükün]särlär (3pl.cond.) 'bow in reverence, ${ }_{2}$ 103-104 ayayur agirlayurlar 'revere ${ }_{2}$ ' 090 ayu see bizin[ä] ayu berin ärmiš see tugar ärmiš berin see bizin[ä] ayu berin berür (3sg.aor.) 'gives' 093 be[s t t]örlüg 'fivefold' 044 birlä 'with' 019

bizin[ä] ayu berin 'tell us!' 026-027

br(a)hmayu bram(a)n 'the brahmin Brahmāyu' 038-039

br(a)hmayu bram(a)n 'the brahmin Brahmāyu' 081 br(a)hmayu p[urokit] 'the purohita Brahmāyu' 032

br(a)hmayu prokid 'Brahmāyu the purohita' 087

bram(a)n see br(a)hmayu bram(a)n sözläyin (1sg.vol.) ‘may I say’ 052

$\mathrm{t}(\mathrm{ä}) \eta \mathrm{ri}$ yerin (acc. 3sg.poss.) 'divine land' 099

[kälmä]k 'coming' 034

[tör]tdin (abl.) 'from the four' 103

birlä 'with' 019

ulug tül[lär] (pl.) 'great dreams' 044-045

olururlar (3pl.aor.) 'sit' 037-038

ogul 'son' 091

külčirä (cvb.) 'smiling' 038

yagd1 'rained' (3sg.prt.) 020

e[ligin] (acc.-3sg.poss.) 'hand[s]' 081 ot(e täprem ) ‘o such ...!' A274b3

ote täprem 'o such' A274a4

tmäș ‘thereupon' A274b4

wināse śla āñcālyī (3pl.prs.-sbj.) 'honour with [their] hands put together' A247b7 (yä)rk yaș (3sg.prs.) ‘honours’ A274b5

wawuräṣ (abs.) ‘having given’ A274b5 päñ 'five' A274a6 śla 'with' A274a2 pākșiñ $\{\tilde{n}\}-\bar{a}-m$ (sg.ipv.-pl.suff.) 'tell us!' A274a3 brahmāyu purohit 'the purohita Brahmāyu' A274a5 (puro)h(i)t 'purohita' A274b3

purohit 'purohita' A274a4

brahmāyu purohit 'Brahmāyu the purohita' A274b4 
bram(a)nla[rka] (dat.pl.) 'to the brahmins' brāmnāśśi (gen.pl.) 'to the brahmins' 092 A274b5

bram(a)nlar tapa 'to the brahmins' 039

burhan kün t(ä)pri 'Buddha the sun-god' $085-086$

but 'Buddha' 025

č(a)kr(a)v(a)rt elig han 'cakravartin king' 072-073

čǎč[äk]lär (pl.) 'flowers' 019

elig see č(a)kr(a)v(a)rt elig han

e[ligin] (acc.-3sg.poss.) 'hand[s]' 081

eštilür (3sg.aor.) 'is heard' 026

han see č(a)kr(a)v(a)rt elig han

iki 'two' 081

inčä tep [te]yür ( cvb. + 3sg.aor.) 'says so' 033

[kädip] (cvb.) 'having put on' 110

[kälmä]k ‘coming' 034

käzigčä 'in a row' 037

körüylär (ipv.pl.) ‘look’ 097

kötürüp see örü kötürüp

kut t(ä)yrisi 'god of glory' 097-098

külčirä (cvb.) 'smiling' 038

kün see burhan kün t(ä)yri

[küntüz] 'by day' 106

maitrilig 'provided with maitrī

(benevolence)' 097

mın see säkiz tümän tört mın

nä 'what' 027

namo 'praise' 025

ogul 'son' 091

[olu]ruylar (2pl.vol.) 'sit down' 035

olururlar (3pl.aor.) 'sit' 037-038

[ö]girip sävinip (cvb.) 'being $\operatorname{glad}_{2}$ ' 032

ögdir anču 'gift,' 093

örü kötürüp (cvb.) 'raising up’ 082

ötrü see anta ötrü

prokid see br(a)hmayu prokid

purokit see br(a)hmayu p[urokit] brā(mnāsac) (all.pl.) 'unto the brahmins'

A274a5

kom-ñkät 'sun-god' A274b4

buddha 'Buddha' A274a3

c(a)kkr(a)v(art)t(i) ‘cakravartin’ A274b2

pyā(ppyāñ) ‘flowers’ (nom.pl.) A274a2

tsaräm (nom.obl.du.) 'hands' A274b3

klyoștär (3sg.prs.mid.) 'is heard' A274a3

āmpi 'both' A274b3

tränkkäṣ (3sg.prs.) 'says’ A274a4

wasu(ṣ) (prt.ptc. nom.pl.m.) 'having put on' A247b8

śämlune 'coming' A274a4

(lyukrā sä)rki 'one after the other' A274a5

pälkāc (ipv.pl.) ‘see’ A274b6

paräṃ-ñkat 'god of glory' A274b6

smimāṃ (prs.ptc.) ‘smiling' A274a5

ykom ‘by day' A274b7

metrakșim 'belonging to Maitreya'

A274b6

ku(s) 'what' A274a3

$\left(\mathrm{n}_{\ddot{a}}\right) \mathrm{m}(\mathrm{o})$ 'praise' A274a3

seyașim 'belonging to a son' A274b5

pälmäs (pl.ipv.) ‘sit down!' A274a4

șmeñc (3pl.prs.) 'sit' A274a5

(kātkmāṃ nāṃ)tsu (prs.ptc. + prt.ptc.)

'being glad' A274a4

dakșiṃ 'gift' A274b5

orto $\mathrm{y} \cdot$ - '(putting) up' A274b3 
säkiz tümän tört mı̣ ‘8(4),000’ 087-088

[säv]iglig 'lovely' 019

sävinip see [ö]girip sävinip

[sizlär] (pl.) 'you' 104

siz[lär tözün]lär (pl.) 'you noble ones’

096-097

sözläyin (1sg.vol.) 'may I say’ 052

tapa see bram(a)nlar tapa

$\mathrm{t}(\mathrm{a}) \eta \mathrm{ri}$ see burhan kün $\mathrm{t}(\ddot{a}) \eta r i$

t(ä)nri yerin (acc. 3sg.poss.) 'divine land' 099

t(ä)yrilärnin (gen.pl.) 'of the gods' 025

$\mathrm{t}(\mathrm{a})$ yrisi see kut $\mathrm{t}(\mathrm{a})$ yrisi

t[äpräd]i 'trembled' (3sg.prt.) 018

tep see inčä tep [te]yür

teyür see inčä tep [te]yür

törlüg see be[š t]örlüg

tört see säkiz tümän tört mı̣

[tör]tdin (abl.) 'from the four' 103

tözünlär see siz[lär tözün]lär

tözünlärim (pl.-1sg.poss.) 'my noble ones' 035

tugar ärmiš 'is being born - as it turns out' 086

tužit 'Tuṣita (heaven)' 099

tüllär see ulug tül[lär]

tümän see säkiz tümän tört min

[tünlä] 'by night' 106

ugrinta 'because of' 091

ulug tül[lär] (pl.) 'great dreams' 044-045

ün 'voice' 026

[y(e)mä] 'also' 104

yer see [yagı] yer

yerin see $\mathrm{t}(\ddot{a}) \eta \mathrm{ri}$ yerin

yagd1 'rained' (3sg.prt.) 020

[yag1z] yer '[grey] earth' 018

$\mathrm{y} 1 \mathrm{ja}[\mathrm{k}]$ 'direction' 103

yükünsärlär see [ayayu agırlayu

yükün]särlär

yüzin (ins.sg.) 'with ... face' 038 okät tmāṃ (śtwar wälts) '8(4),000'

A274b4

ciñcrạ̣ (pl.f.) 'lovely’ A274a2

yas (pl.) 'you' A274b7

klyomäṣ (nom.pl.m. as voc.) 'nobles

ones' A274b6

(w)eñim (1sg.opt.) 'may I say’ A274a7

wșeññe ‘place' A274b6

ñäktaśśi (gen.pl.) ‘of the gods’ A274a3

meyā 'trembled' (3sg.ipf.) A274a2

(śtwa)r 'four' A274b7

klyo(mäș) (nom.pl.m. as voc.) 'o noble ones' A274a4

pärkatär (3sg.prs.) 'rises' A274b4

tuṣitșim 'belonging to the Tuṣita

(heaven)' A274b6

o(șeñi) 'by night' A274b7

$\bar{a}(\mathrm{ka} l)$ ? 'wish' A274b5

șäpnant (pl.) ‘dreams’ A274a6

rake 'word' A274a3

penu 'also' A274b7

svawrä (3pl.ipf.; for sawrä) 'rained down' A274a2

tkam 'earth' A274a2

kälymentwāṣ (abl.pl.) 'from the directions' A274b7

akmalyo (ins.sg.) 'with ... face' A274a5 


\section{References}

Burlak, Svetlana A. - Itkin, Il'ja B. (2004): Toxarskij tekst A 446: eščë odna rukopis' toxarskoj versii Maitreyasamiti-Nātaka. Voprosy Jazykoznanija No. 3, pp. 24-35.

Carling, Gerd (2009): Dictionary and Thesaurus of Tocharian A. Part 1: A-J. Compiled by Gerd Carling, in collaboration with Georges-Jean Pinault and Werner Winter. Wiesbaden, Harrassowitz.

CETOM = A Comprehensive Edition of Tocharian Manuscripts. www.univie.ac.at/tocharian

Erdal, Marcel (2004): A Grammar of Old Turkic. Leiden-Boston, Brill.

Geng Shimin - Klimkeit, Hans-Joachim - Laut, Jens Peter (1988): „Das Erscheinen des Bodhisattva““. Das 11. Kapitel der Hami-Handschrift der Maitrisimit. Altorientalische Forschungen Vol. 15, pp. 315-366.

Geng Shimin -Laut, Jens Peter-Pinault, Georges-Jean (2004): Neue Ergebnisse der MaitrisimitForschung. Zeitschrift der Deutschen Morgenländischen Gesellschaft Vol. 154, pp. 347369.

Israpil, Dilara [Dilana Yisilafei'er] (2009): Xinjiang bowuguan cang shengjinkou ben "Mile hui jian ji" yanjiu. In: Zhang Dingjing-Yakup, Abdurishid (eds): Tujue yuwenxue yanjiu. Geng Shimin jiaoshou bashi huadan jinian wenji. - Studies in Turkic Philology. Festschrift in Honour of the 80th Birthday of Professor Geng Shimin. Beijing, Minzu Chubanshe, pp. $81-97$.

Israpil, Dilara (2013): The Old Uighur Maitrisimit Preserved in the Xinjiang Museum: A Study of Four Fragments of the Sängim Versions. In: Kasai, Yukiyo-Yakup, Abdurishid-DurkinMeisterernst, Desmond (eds): Die Erforschung des Tocharischen und die alttürkische Maitrisimit. Turnhout, Brepols, pp. 51-66.

Israpil, Dilara [Dilana Yisilafei'er] (2015): Tulufan faxian Huihuwen fojiao xin wenxian yanjiu. Beijing, Minzu Chubanshe.

Israpil, Dilara-Laut, Jens Peter-Semet, Ablet (2013): Neu entdeckte Bruchstücke der Maitrisimit aus Närnasi in Qomul (VR China). Ural-Altaische Jahrbücher N.F. Vol. 25, pp. 220-227.

Laut, Jens Peter (1986): Der frühe türkische Buddhismus und seine literarischen Denkmäler. Wiesbaden, Harrassowitz.

Müller, Friedrich W. K.-Sieg, Emil (1916): Maitrisimit und »Tocharisch«. Sitzungsberichte der Königlich Preussischen Akademie der Wissenschaften. Berlin, pp. 395-417.

Peyrot, Michaël (2013): The Tocharian Subjunctive. A Study in Syntax and Verbal Stem Formation. Leiden-Boston, Brill.

Pinault, Georges-Jean (1999): Restitution du Maitreyasamiti-Nātaka en tokharien A: Bilan provisoire et recherches complémentaires sur l'acte XXVI. Tocharian and Indo-European Studies Vol. 8, pp. 189-240.

Pinault, Georges-Jean (2003): Contacts linguistiques en Asie Centrale à la lumière des textes tokhariens. In: Bretfeld, Sven-Wilkens, Jens (eds): Indien und Zentralasien, Sprach- und Kulturkontakt. Vorträge des Göttinger Symposions vom 7. bis 10. Mai 2001. Wiesbaden, Harassowitz, pp. 45-83.

Pinault, Georges-Jean (2008): Chrestomathie tokharienne. Textes et grammaire. Leuven-Paris, Peeters.

Pinault, Georges-Jean (2015): Dramatic Works: Central Asia. In: Silk, Jonathan A. (ed.): Brill's Encyclopedia of Buddhism. Volume 1. Literature and Languages. Leiden-Boston, Brill, pp. $584 \mathrm{a}-590 \mathrm{~b}$.

Röhrborn, Klaus (1977-1998): Uigurisches Wörterbuch, Sprachmaterial der vorislamischen türkischen Texte aus Zentralasien. Wiesbaden, Steiner. 
Schmidt, Klaus T. (1974): Die Gebrauchsweisen des Mediums im Tocharischen. Dissertation, Göttingen.

Semet, Ablet-Äysa, Ali (2015): Prophezeiung über die Maitreya-Geburt. Neues zum 11. Kapitel der uighurischen Maitrisimit nom bitig. In: Mirsultan, Aysima-Aydın, Mihriban TursunAydın, Erhan (eds): Eski Türkçeden Çağdaş Uygurcaya. Mirsultan Osman'ın Doğumunun 85. Yllına Armağan - From Old Turkic to Modern Uyghur. Festschrift in Honor of Mirsultan Osman on the Occasion of his 85th Birthday. Konya, Kömen Yayınları, pp. 221-249.

Sieg, Emil-Siegling, Wilhelm (1921a): Tocharische Sprachreste, I. Band. Die Texte. A. Transcription. Berlin-Leipzig, de Gruyter.

Sieg, Emil-Siegling, Wilhelm (1921b): Tocharische Sprachreste, I. Band. Die Texte. B. Tafeln. Berlin-Leipzig, de Gruyter.

Thomas, Werner (1954): Die Infinitive im Tocharischen. In: Schubert, Johannes-Schneider, Ulrich (eds): Asiatica. Festschrift Friedrich Weller, Zum 65. Geburtstag gewidmet von seinen Freunden, Kollegen und Schülern. Leipzig, Harrassowitz, pp. 701-764.

Thomas, Werner (1957): Der Gebrauch der Vergangenheitstempora im Tocharischen. Wiesbaden, Harrassowitz.

Yoshida, Yutaka (1991): Shinkyō Uiguru jichiku shinshutsu Sogudo-go shiryō - Reports on the Sogdian Texts Newly Discovered in Xinjiang. Studies on the Inner Asian Languages Vol. 6 (1990), pp. 57-83. 